\title{
Obituaries
}

\section{THOMAS OWEN HUGHES}

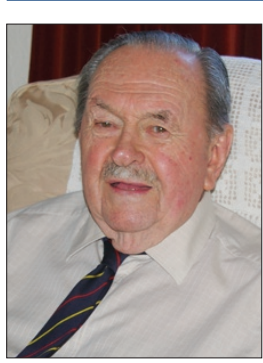

Dr Thomas 'Tom' Hughes (19172010), in common with many of his generation, had a long and productive career. His was distinguished by his studying medicine initially then dentistry as his career progressed.

Born and raised at Fferam Fawr Farm on the island of Anglesey, North Wales in 1917, Tom went to the local primary school then matriculated from Holyhead County School.

He studied medicine at Liverpool University and following graduation he joined the Army Medical Corps during the war years. He returned to Liverpool with the initial thought of following a career in orthopaedics but the lure of dentistry proved too great. Three further years of study saw him graduate as a dentist, again at Liverpool University. His first practice was at Broadgreen in Liverpool; during this time (1949) he married Margaret. Shortly before the birth of his second son, he moved back to Anglesey in 1954, setting up a practice in Llangefni. The loss of his wife Margaret was a severe blow in 1976. Despite this he continued in general dental practice for the rest of his working life until his retirement in 1982.

Happily Tom was re-married in 1980 to Dorothy with whom he had a long and contented retirement.

In his youth, Tom was an athlete but from 1935 he was a keen devotee of golf being a member of the same club up to his passing. As well as enjoying gardening Tom was a notable and skilled jewel- ler using his expertise in the 'lost wax' technique to good effect.

Tom is survived by Philip and Rodney his sons as well as Dorothy his devoted wife. The local community will mourn his loss as a professional of the old school; his family mourn the loss of a kind and devoted father and husband.

\section{R. Davies}

\section{ALISTAIR CAMPBELL McLUNDIE}

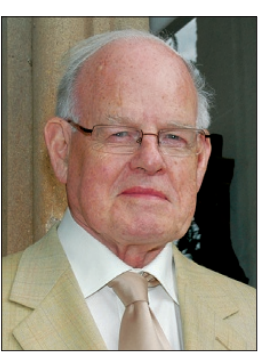

Alastair Campbell McLundie, who has died in his eightieth year, was a highly respected member of staff in the Conservation Department of Glasgow Dental Hospital and

School for many years.

Born in Milngavie near Glasgow in 1930, Alastair's family owned the City Glass Company which was responsible for the stained glass in many churches and public buildings around Glasgow. His education at The High School of Glasgow was interrupted by evacuation, in Alastair's case to Argyll; in later life he spoke fondly of those days at Glencoe. In 1948 Alastair matriculated at Glasgow University into the second year of the new Bachelor of Dental Surgery course and went on to graduate with distinction in 1953.

Travel during university holidays, camping and hostelling, had always been an interest of Alastair's; on returning from a post-graduation trip he found his calling-up papers awaiting him. In September 1953 he reported to Royal Army Dental Corps headquarters at Aldershot.
Obituaries should be submitted by email to Kate Maynard at k.maynard@nature.com.

All submitted obituaries should be 350 words maximum in length (apart from obituaries for past presidents of the BDA where the length should be 700-800 words). Content of the obituary is down to the individual author, and the approval of the family should be given for the obituary prior to submission to the $B D J$.

After a few months in England he was posted to Malaya (now Malaysia) during the Malayan Emergency. After 25 days on board the 'Empire Orwell', Alastair landed at Singapore and was immediately attached to 16th Field Ambulance and then to British Military Hospital at Kluang in Johore State. It was there that he met Lieutenant Una Bunce QARANC who was to become his wife in 1956.

On return to civilian life Alastair worked for two years in general practice in Clydebank and Govan before joining the university staff at Glasgow Dental Hospital and School.

Subsequently he became a Senior Lecturer in Conservation with the NHS rank of Honorary Consultant. He will be remembered fondly by the hundreds of dental students he taught and guided through their years of study as a kindly mentor, and also by many members of staff in other departments and dental schools.

Una cared for Alastair in his declining health in recent years but as his health deteriorated the family decided that he required specialised care. Alastair is survived by Una, his devoted wife of 53 years, sons Campbell and William, daughters Alison and Elspeth, four grandchildren and his brother Murray.

GDCK \& EWS 